\title{
Health-promoting lifestyles and related factors among pregnant women
}

\author{
Güliz Onata, Yılda Arzu Abab
}

\begin{abstract}
Objective: A health-promoting lifestyle has an especially important role during pregnancy due to its direct link to healthy births, and to low maternal-fetal mortality and morbidity rates. The objectives of our study are to determine and analyse the health-promoting lifestyles and related factors in pregnant women. Methods: This descriptive study was carried out on 255 pregnant women in the city of Usak in Turkey, using the Health-Promoting-Lifestyle-Profile-II-(HPLP). Frequencies, percentage distributions, $t$ tests, and the Mann Whitney $U$ test and ANOVA were used to analyze the results. Results: The mean age of the pregnant women was $26.7 \pm 5.1$ and their mean gestational week was $25.2 \pm 10.9$. The mean total score on the HPLP was $130.7 \pm 20.0$. The lowest score was for "physical activity" (14.4 \pm 5.0$)$. The highest score was for "psychological wellbeing" (26.18 \pm 4.2 ). Smoking prevalence among the study population was $17 \%$ before the pregnancy, and 3.9\% during the pregnancy (with an average of 4 cigarettes/day). During the pregnancy diet habits improved. The rate of giving up smoking was high. Women also sought further knowledge about pregnancy and birth. Conclusions: In pregnant women the HPLP score was upper to intermediate in level. Of the women who participated in the survey, those that were unemployed, had a lower level of education, and those who had considered abortion were found to be at a higher risk of not having a health promoting life style. This finding provides a unique insight in identifying the risk group for health care providers who work at an antenatal clinic. Health caregivers should pay more attention to this risk group when evaluating healthy lifestyles during whole pregnancy.
\end{abstract}

Key Words: Health-Promoting Lifestyles; pregnant women; Health Promoting Lifestyle Profile-II

\section{Gebelerde sağlıklı yaşam biçimi davranışları ve ilişkili faktörler}

\section{Özet}

Amaç: Sağlıklı yaşam biçimi davranışları; sağlıklı ve canlı bir doğum yapma, anne-yenidoğan mortalite ve morbidite oranını azaltma açısından özellikle gebelik sürecinde oldukça önemlidir. $\mathrm{Bu}$ çalışmada gebe kadınlaın sağlıklı yaşam biçimi davranışları ve ilişkili faktörlerinin araştırılması amaçlanmıştır. Yöntem: Tanımlayıcı nitelikte olan bu çalışma, Uşak'ta 255 gebe kadın üzerinde gerçekleşmiştir. Çalışmada Sağlıklı Yaşam Biçimi Davranışları Ölçeği-II (SYBDÖII) kullanılmıștır. İstatistiksel değerlendirmede sıklık ve yüzdelik dağılım, t test, Mann Whitney U test and ANOVA kullanılmıştır. Bulgular: Kadınların yaş ortalaması $26.7 \pm 5.1$ ve gestasyonel yaşı 25.2 \pm 10.9 haftadır. Toplam SYBDÖ-II puanı 130.7. \pm 20.0 idi. Ölçeğe ait en düşük puan "fiziksel aktivite" alt grubuna, (14.4 \pm 5.0$)$ en yüksek puan ise "manevi gelişim" e aittir (26.1 \pm 4.2$)$. Gebelik öncesi sigara içme sıklığı \%16.9 iken, gebelikte bu oran \%3.9'dur (ortalama 4 sigara/gün).

a Assis. Prof. Dr., Istanbul Aydin Uni., Faculty of Health Sciences, Head of Nursing Department

b Assis. Prof. Dr., Istanbul Aydin Uni., Faculty of Health Sciences, Nursing Department

Corresponding Author: Güliz Onat, Istanbul Aydin U., Faculty of Health Sciences, Nursing Dept. H Blok 4. floor No:6410, Besyol Mah. Inonu Cad. No: 38, Sefakoy-Kucukcekmece, 34295, Istanbul, Turkey, Phone: 00904441 428- 28001; E-mail: gulizonat@hotmail.com

Received date: 13.03.2013, Accepted date: 19.03.2014

Turk J Public Health 2014;12(2) 
Kadınların gebelikte beslenme alışkanlıkları iyileşmiştir; öte yandan halen sigara içen gebeler bulunmaktadır ve fiziksel aktivitelerindeki değişimler yetersizdir. Ayrıca kadınlar gebelik ve doğum hakkında bilgi alma gereksinimindedir. Sonuç: Gebe kadınlarda SYBDÖ-II puanı üst-orta seviyededir. Eğitim seviyesi düşük, işsiz ve gebeliğini sonlandırmak isteyen kadınların, sağlıksız davranışlar açısından risk grubunda olduğu belirlenmiştir. $\mathrm{Bu}$ bulgular, doğum öncesi kliniklerde çalışan sağlık personeline riskli grubu belirleme açısından ipuçları sunar. Sağlık bakımı sunanların, sağlıklı yaşam biçimi davranışları açısından belirlenen riskli grubu daha dikkatli değerlendirilmesi önerilmektedir.

Anahtar Kelimeler: Sağlıklı Yaşam Biçimi Davranışları; gebe kadınlar; Sağlıklı Yaşam Biçimi Davranışları Ölçeği-II

\section{Introduction}

Health-promoting lifestyles are viewed as a multi-dimensional pattern of self-initiated actions and perceptions that serve to maintain or enhance the level of wellbeing, self-actualization, and fulfilment of the individual1. These includes six domains, which are individual nutrition, physical activity, stress management, interpersonal relationships, psychological wellbeing and health responsibility. ${ }^{1,2}$ Individuals who incorporate these factors into their lifestyle are likely to be rewarded by an improved and stable health status. ${ }^{3}$ All these factors have an especially important role during pregnancy, which is a pivotal time in a woman's life. ${ }^{4}$

Health-promoting lifestyles related to pregnancy consist of modifiable or preventable factors such as smoking, obesity, age of pregnancy, diet, abstaining from teratogens, protection from sexually transmitted infections.5,6 "Factors such as excessive consumption of caffeine, smoking, or alcohol, having an unhealthy diet, being overweight, inadequate exercise, or environmental pollution affect the successful birth. ${ }^{7}$ Many reports have indicated that these unhealthy behaviours can cause a low birth weight. ${ }^{8-10}$ Stacy, et al., (1994) further showed that smoking can cause premature births or the sudden infant death syndrome and increase the rate of spontaneous abortion (miscarriage). ${ }^{10}$ Excessive alcohol intake can lead to the fetal alcohol syndrome, and to intra-uterine growth retardation, central nervous system problems, and mental retardation of the fetus. ${ }^{8}$ Hence, it is be helpful to promote a healthy lifestyle for mother and infant health. 1,6

The potential related to a woman's health-promoting lifestyles include personal characteristics (such as age and socioeconomic status), health behaviours (e.g., exercising), perceived health status, selfefficacy of health behaviours, and perception of family or of peers' health promoting behaviours (a kind of social support). These are shown in (Fig. 1)



Figure 1. The related factors of pregnant women's health-promoting lifestyles. ${ }^{1}$

There has been research previously in Turkey related to health promotion during pregnancy. In their study of high risk pregnancies among Turkish women, Saydam, et al. (2007) found that the mean HPLP II score was 121.3 \pm 21.0 .4 Altıparmak and Kutlu (2009) reported that it was 
112.7 \pm 20.8 among women aged 15-49 chosen by a random sampling method from the Turkish city of Manisa. ${ }^{11}$ Sayan (1998) found that it was $122.5 \pm 14.5$ among employed women. ${ }^{12}$ Doğu and Ergin (2008) found that $11.6 \%$ of women smoked during their pregnancies. ${ }^{13}$ Altıparmak, Altıparmak and Avcl (2008) reported that 19.1\% of pregnant women were smoking during their pregnancy. ${ }^{14}$ Gümüş et al. (2010) found that according to gestational weight gain $39.3 \%$ of pregnant women gained $>16 \mathrm{~kg}$ during the pregnancy. ${ }^{15}$ Noğay (2011) reported that individuals were not changing the amount of their food consumption during pregnancy. In addition pregnant women usually had lower than recommended levels of nutrient intake. ${ }^{16}$

Since pregnancy is a different part of the overall life style, this study tried to evaluate the relationship between healthy pregnancy and lifestyle with related factors.

\section{Materials and Methods}

This descriptive research was conducted at an obstetrics department at the state hospital in Uşak inTurkey between October 2010 and November 2011. Uşak is a city located in southwestern Turkey. In 2011 its population was approximately $340,000 .{ }^{17}$ Its main economic income is based on industry and agriculture. $65 \%$ of the total population lives in urban areas, while $26 \%$ and $9 \%$ live in villages and towns, respectively. The current study was conducted in the city center which is the most densely populated area.

The population of the study was pregnant women attending clinic of the obstetrics department. The criteria for selection were: (i) not having any mental or physical illness according to medical records, (ii) volunteering to participate in the current study. The justification of the sample criteria was to control for any external factors such as disease, which might have a negative or positive effect on health-promoting lifestyles.

601 pregnant women attended an antenatal visit at the clinic between October
2010 and November 2011; 255 off these pregnant women were included in the study.

Data were collected with a questionnaire prepared by the researchers, which addressed the socio-demographical and obstetrical characteristics of the women. The questionnaire also included a part related to the changes of lifestyle during pregnancy. The lifestyle of the women was measured using the Health Promoting Lifestyle Profile-II (HPLP). The HPLP and the questionnaire were filled out by the pregnant women by themselves. The questionnaire contained socio-demographic characteristics, obstetric and marital history, nutritional habits and behaviours related to health promoting lifestyles.

The HPLP questionnaire contained a 52-item, multidimensional self-report that assessed daily activities using six subscales: nutrition, physical activity, stress management, interpersonal relationships, psychological wellness, and health responsibility. These were rated on a 4point Likert scale, ranging from 1 (never) to 4 (always). ${ }^{18}$ HPLP П scores ranged from 52 to 208; higher scores indicate better healthpromoting lifestyles. Cronbach's $\alpha$ for the HPLP $\Pi$ total scale was 0.96 and for the subscales ranged from 0.79 to 0.87 . HPLP II was translated and adopted into Turkish by Esin (1997) ${ }^{19}$, Akça (1998) ${ }^{20}$, and by Bahar, et al. (2008). ${ }^{21}$ In this study, the most current version by Bahar et al. was used ${ }^{21}$. Cronbach's $\alpha$ for the Turkish version of the HPLP $\Pi$ was 0.92 and for each subscale ranged from 0.64 to 0.80 . Cronbach's $\alpha$ for our study was 0.92 and that for each subscale ranged from 0.65 to 0.86 .

Other variables such as perceived health status, economic status and planned pregnancy were also investigated. Perceived health status was assessed by the following question: "How would you describe your health status? Options were "excellent; good; fair; poor; very poor". Economic status was assessed by the following question: "Which of the following most represents your economic status? Options were "lower expense than income; income equal to expenses; higher expense than 
income". Planned pregnancy was assessed with the following question: "Was the pregnancy planned?" Options were yes or no.

Written ethical approval was obtained from the ethical review board of the hospital. Participants were informed about the aims of this study and their written consent was obtained prior to the distribution of the questionnaire.

\section{Statistical analysis}

The Statistical Package for the Social Sciences (SPSS), release version 15.0, was used for data analysis. To detect any significant statistical differences between two groups the $t$ test for a normal distribution and the Mann-Whithey $U$ test for non-normal distribution were used. For comparison of more than two groups a One Way Anova or the Kruskall-Wallis tests were used. A $p$ value smaller than $5 \%$ was considered as significant.

\section{Results}

The mean age of the pregnant women was $26.7 \pm 5.1$, and ages ranged from $17-43$ years. The $20-35$ age group provided $89.5 \%$ of the data (Data not shown). Most of the women $(70 \%)$ were housewives while the remaining women were employed including $5 \%$ of the were civil servant. Most of the women $(56 \%)$ had high school or higher levels of education $71 \%$ of the women declared their income and expenditure as equal. 51.8\% lived in an apartment and $75.3 \%$ of the women had a nuclear family (consisting of parent and children) (Table 1).

In their obstetrical history, $37.3 \%$ were primigravidas, $78 \%$ had never experienced a miscarriage, and 91\% had never had an abortion. The mean gestational duration was $25.2 \pm 10.9$ weeks. Two questions were asked about potential effects on health factors in pregnancy. They are (i) whether the pregnancy was desired, and (ii) whether they had considered terminating the pregnancy: $16.1 \%$ had not planned the pregnancy, and $9.8 \%$ had considered terminating the pregnancy.
Among the women 92.2\% reported not having a chronic disease, whilst $5 \%$ had experienced allergic rhinitis. One participant reported a diagnosis of diabetes. Of the participants, $59.6 \%$ declared their health status as "good" and $11.8 \%$ as "excellent". In addition, 92.5\% had regular prenatal visits during pregnancy.

Table 1. Socio-demographic Characteristics of Pregnant Women $(\mathrm{n}=255)$

\begin{tabular}{lcc}
$\begin{array}{l}\text { Socio-demographic } \\
\text { Characteristics }\end{array}$ & $\mathrm{n}$ & $\%$ \\
\hline $\begin{array}{l}\text { Educational level } \\
\text { No formal education }\end{array}$ & 4 & 1.6 \\
Primary School & 65 & 25.5 \\
Secondary School & 43 & 16.9 \\
High School & 72 & 28.2 \\
University & 71 & 27.8 \\
Working status & & \\
Working & 77 & 30.2 \\
Not working & 178 & 69.8 \\
Whether the & & \\
pregnancy & & \\
was planned & & \\
Yes & & \\
No & 214 & 83.9 \\
Whether they had & 41 & 16.1
\end{tabular}

Whether they had

considered

terminating the

pregnancy

$\begin{array}{lll}\text { Yes } & 25 & 9.8\end{array}$

$\begin{array}{lll}\text { No } & 230 & 90.2\end{array}$

Economic status

Expenses lower than $23 \quad 9.0$

income

Income equals expenses $\quad 181 \quad 71.0$

expenses higher than $51 \quad 20.0$

income

Family type

$\begin{array}{lll}\text { Nuclear family } & 192 & 75.3\end{array}$

Extended family

$63 \quad 24.7$

Perceived health

$\begin{array}{lll}\text { Excellent } & 30 & 11.8\end{array}$

Good $\quad 152 \quad 59.6$

Fair $\quad 65 \quad 25.5$

$\begin{array}{lll}\text { Poor } & 8 & 3.1\end{array}$

$\begin{array}{lll}\text { Very poor } & 0 & 0.0\end{array}$ 
The mean of the total score for HPLP II was $130.7 \pm 20.0$ (min. 80, max. 192). The score for physical activity was the lowest (14.4 \pm 5.0$)$ while the score of psychological wellbeing was the highest $(26.1 \pm 4.2)$. The other scores were measured as $25.4 \pm 4.2$, $22.9 \pm 4.6, \quad 21.9 \pm 4.0, \quad 19.9 \pm 3.8$ for interpersonal relationships, health responsibility, nutrition, and stress management, respectively.

HPLP II scores were compared according to several factors. There was a statistically significant relationship between the total HPLP II score and the level of education; economic status, employment status and family type $(\mathrm{p}<0.05$ for all) (Table 2).

The nutrition, stress management, and total HPLP-II scores were higher for women who live in a nuclear family than for those who live in extended families (Consisting of a live-in grandmother, grandfather or other immediate members of the family). There were significant differences between economic level and some items such as physical activity, stress management and total score among the 3 economic categories (Table 2). The higher income than expense group had a significantly higher score for total HPLP II ( $t: 2.36, \mathrm{p}: 0.01$ ) and for the physical activity score $(\mathrm{t}: 4.23, \mathrm{p}<0.01)$ than did the income equalling expenses group. In addition the higher income than expenses group had significantly higher scores for total HPLP II (Z: 2,43, p: 0.01), physical activity (Z:2.17, $\mathrm{p}: 0.02)$ and stress management (Z: 2.51, $\mathrm{p}: 0.01)$ than that did the lower expense than income group.

There was no association between the HPLP-II score and number of the pregnancy. However, the subscale score for stress management was better among women who had planned their pregnancy than it was for those who had considered a termination $(\mathrm{p}<0.05)$. In addition, the total HPLP II scores for health responsibility and for stress management were lower in the group who had considered terminating the pregnancy than in the group who had planned their pregnancy (Data is not shown).
Comparing the declared health status with the HPLP II subscales, there was a significant difference between the good health and fair to poor health groups recorded. The good health group had higher scores for psychological wellbeing ( $\mathrm{t}$ : 2.07, $\mathrm{p}=0.03$ ) and stress management ( $\mathrm{t}: 3.05$, $\mathrm{p}<0.01$ ) than did the fair-poor health group (Data are not shown).

The study found that the $16.9 \%$ of the women were smoking before their pregnancy; this was 3.9\% during pregnancy. None of the women used alcohol during the pregnancy; $98.8 \%$ had not used alcohol before the pregnancy. In the history of their current dietary habits, the average consumption of tea was $2.9 \pm 2.1$ cups/day, and coffee consumption was $0.5 \pm 1.0$ cups/day.

The women were asked, 'What kind of dietary changes have you made during the pregnancy?'. Twelve percent of women reported having made no dietary change during the pregnancy; $67.1 \% \mathrm{~m}$ reported an increased intake of fluids. Half of the women reported increased intake of calcium (50.2\%), $76.5 \%$ an increased intake of vegetables and fruits and $47.8 \%$ reported an increase in the daily number of meals. In addition $55.7 \%$ of women reported a decreased intake of caffeine, and carbonated drinks (57.3\%) (Data are not shown).

When women were asked if they had made any lifestyle changes to improve their health, $90.2 \%$ of them responded positively. Almost $64 \%$ of them had abstained from hard activity. $63.1 \%$ reported that they had sought knowledge about pregnancy and birth; in addition $5.9 \%$ of them attended an antenatal education class. Half of them reported that their sleeping hours had increased. Answers are shown in Table 3. 
Table 2. Factors associated with HPLP- II scores

\begin{tabular}{|c|c|c|c|c|c|c|c|}
\hline Factors & $\begin{array}{l}\text { Health } \\
\text { Responsibility }\end{array}$ & Physical Activity & Nutrition & $\begin{array}{l}\text { Psychological } \\
\text { Wellness }\end{array}$ & $\begin{array}{l}\text { Interpersonal } \\
\text { Relationship }\end{array}$ & $\begin{array}{l}\text { Stress } \\
\text { Management }\end{array}$ & Total Score \\
\hline \multicolumn{8}{|l|}{ Educational Level } \\
\hline $\begin{array}{l}\text { Less than high school } \\
(\mathrm{n}: 134)\end{array}$ & $21.4 \pm 4.1$ & $12.8 \pm 4.4$ & $21.6 \pm 4.1$ & $25.0 \pm 3.8$ & $24.3 \pm 4.0$ & $19.0 \pm 3.6$ & $124.3 \pm 18.0$ \\
\hline $\begin{array}{l}\text { High school and } \\
\text { above(n:121) }\end{array}$ & $24.7 \pm 4.4$ & $16.1 \pm 5.1$ & $22.8 \pm 3.7$ & $27.0 \pm 4.3$ & $26.5 \pm 4.0$ & $20.9 \pm 3.9$ & $138.2 \pm 19.5$ \\
\hline T test & $\mathrm{t}=6.0 \mathrm{p}=0.00^{*}$ & $\mathrm{t}=5.3 \mathrm{p}=0.00^{*}$ & $\mathrm{t}=3.3 \mathrm{p}=0.00^{*}$ & $\mathrm{t}=3.2 \mathrm{p}=0.00^{*}$ & $\mathrm{t}=4.0 \mathrm{p}=0.00^{*}$ & $\mathrm{t}=4.1 \mathrm{p}=0.00^{*}$ & $\mathrm{t}=5.9 \mathrm{p}=0.00^{*}$ \\
\hline \multicolumn{8}{|l|}{ Working status } \\
\hline Working & $24.6 \pm 4.7$ & $16.5 \pm 5.2$ & $22.5 \pm 3.8$ & $26.6 \pm 5.0$ & $26.3 \pm 4.6$ & $20.9 \pm 4.0$ & $137.7 \pm 21.5$ \\
\hline T Test & $\mathrm{t}=3.7 \mathrm{p}=0.00^{*}$ & $\mathrm{t}=4.6 \mathrm{p}=0.00^{*}$ & $\mathrm{t}=1.5 \mathrm{p}=0.11$ & $\mathrm{t}=1.2 \mathrm{p}=0.20$ & $\mathrm{t}=2.1 \mathrm{p}=0.00^{*}$ & $\mathrm{t}=2.6 \mathrm{p}=0.00^{*}$ & $\mathrm{t}=3.6 \mathrm{p}=0.00^{*}$ \\
\hline \multicolumn{8}{|l|}{$\begin{array}{l}\text { Whether the pregnancy } \\
\text { was planned }\end{array}$} \\
\hline Yes & $23.2 \pm 4.6$ & $14.4 \pm 5.0$ & $22.0 \pm 4.1$ & $26.2 \pm 4.2$ & $25.6 \pm 4.2$ & $20.2 \pm 3.9$ & $131.9 \pm 20.5$ \\
\hline No & $21.5 \pm 3.9$ & $14.2 \pm 5.0$ & $21.3 \pm 3.7$ & $25.6 \pm 4.0$ & $24.6 \pm 3.7$ & $18.6 \pm 3.4$ & $126.1 \pm 16.6$ \\
\hline T Test & $\mathrm{t}=2.2 \mathrm{p}=0.02^{*}$ & $\mathrm{t}=0.1 \mathrm{p}=0.02$ & $\mathrm{t}=1.0 \mathrm{p}=0.30$ & $\mathrm{t}=0.8 \mathrm{p}=0.41$ & $t=1.4 p=0.16$ & $\mathrm{t}=2.4 \mathrm{p}=0.01^{*}$ & $\mathrm{t}=1.0 \mathrm{p}=0.09$ \\
\hline
\end{tabular}


Table 2. Factors associated with HPLP- II scores (Continue)

\begin{tabular}{|c|c|c|c|c|c|c|c|}
\hline Economic Status** & & & & & & & \\
\hline $\begin{array}{l}\text { Expense lower than } \\
\text { income } \\
(n: 23)\end{array}$ & $21.5 \pm 4.0$ & $14.0 \pm 4.5$ & $22.0 \pm 4.9$ & $24.7 \pm 4.2$ & $24.5 \pm 3.2$ & $18.5 \pm 4.0$ & $125.3 \pm 19.7$ \\
\hline $\begin{array}{l}\text { Income equals expenses } \\
\text { (n:181) }\end{array}$ & $23.0 \pm 4.6$ & $13.7 \pm 4.7$ & $21.7 \pm 4.0$ & $26.1 \pm 3.8$ & $25.4 \pm 4.1$ & $19.8 \pm 3.8$ & $129.9 \pm 19.2$ \\
\hline $\begin{array}{l}\text { Expense higher than } \\
\text { income } \\
(\mathrm{n}: 51)\end{array}$ & $23.5 \pm 4.6$ & $17.0 \pm 5.5$ & $22.8 \pm 3.7$ & $26.9 \pm 5.3$ & $26.1 \pm 4.6$ & $20.7 \pm 3.7$ & $137.3 \pm 21.7$ \\
\hline Kruskal-Wallis Test & $\mathrm{X}^{2}=3.5 \mathrm{p}=0.16$ & $\mathrm{X}^{2}=14.8 \mathrm{p}=0.00^{*}$ & $\mathrm{X}^{2}=3.2 \mathrm{p}=0.19$ & $\mathrm{X}^{2}=5.2 \mathrm{p}=0.07$ & $\mathrm{X}^{2}=2.6 \mathrm{p}=0.26$ & $\mathrm{X}^{2}=7.3 \mathrm{p}=0.02^{*}$ & $\begin{array}{l}\mathrm{X}^{2}=8.9 \\
\mathrm{p}=0.01^{*}\end{array}$ \\
\hline
\end{tabular}

\begin{tabular}{|c|c|c|c|c|c|c|c|}
\hline \multicolumn{8}{|l|}{ Family Type } \\
\hline Nuclear family & $23.2 \pm 4.7$ & $14.6 \pm 13.8$ & $22.2 \pm 4.0$ & $26.3 \pm 4.2$ & $25.6 \pm 4.1$ & $20.2 \pm 19.0$ & $132.3 \pm 20.2$ \\
\hline Entended family & $22.2 \pm 4.2$ & $13.8 \pm 4.7$ & $21.0 \pm 3.9$ & $25.6 \pm 4.0$ & $24.9 \pm 4.2$ & $19.0 \pm 3.4$ & $126.6 \pm 18.8$ \\
\hline T Test & $t=1.4 p=0.15$ & $\mathrm{t}=1.0 \mathrm{p}=0.27$ & $\mathrm{t}=2.2 \mathrm{p}=0.02^{*}$ & $\mathrm{t}=1.2 \mathrm{p}=0.21$ & $\mathrm{t}=1.1 \mathrm{p}=0.26$ & $\mathrm{t}=2.2 \mathrm{p}=0.02^{*}$ & $t=1.9 p=0.04^{*}$ \\
\hline Excellent (n:30) & $23.5 \pm 4.8$ & $14.1 \pm 5.0$ & $21.6 \pm 4.8$ & $27.6 \pm 4.3$ & $27.0 \pm 3.9$ & $20.8 \pm 3.3$ & $134.7 \pm 21.2$ \\
\hline Good (n:152) & $23.1 \pm 4.6$ & $14.5 \pm 4.7$ & $22.0 \pm 3.8$ & $26.3 \pm 4.1$ & $25.4 \pm 4.1$ & $20.3 \pm 3.9$ & $132.0 \pm 19.7$ \\
\hline Fair-Poor (n:73) & $22.3 \pm 4.4$ & $14.2 \pm 5.6$ & $21.8 \pm 4.2$ & $25.1 \pm 4.1$ & $24.8 \pm 4.3$ & $18.6 \pm 3.6$ & $127.1 \pm 19.9$ \\
\hline ANOVA & $\mathrm{F}=0.9 \mathrm{p}=0.38$ & $\mathrm{~F}=0.1 \mathrm{p}=0.83$ & $\mathrm{~F}=0.1 \mathrm{p}=0.84$ & $\mathrm{~F}=4.1 \mathrm{p}=0.01^{*}$ & $\mathrm{~F}=3.0 \mathrm{p}=0.04^{*}$ & $\mathrm{~F}=5.7 \mathrm{p}=0.00^{*}$ & $\mathrm{~F}=2.0 \mathrm{p}=0.12$ \\
\hline
\end{tabular}

${ }^{*} \mathrm{p}<0.05$ F: One-Way ANOVA t: Student t test ${ }^{* *}$ : The group which causes to difference is shown at the results section 
Table 3. Changes in lifestyle during pregnancy

\begin{tabular}{lcc}
\hline Lifestyles & $\mathrm{n}$ & $\%$ \\
I have begun abstaining from hard activities & 163 & 63.9 \\
I took the medicine regularly that was suggested by my doctor & 161 & 63.1 \\
I sought information regarding pregnancy and delivery & 161 & 63.1 \\
I maintained a regular and balanced nutrition & 149 & 58.4 \\
I have increased the frequency of hygienic habits & 148 & 58.0 \\
(bathing, showering, etc.) & & \\
I tried to avoid stressful situations & 133 & 52.2 \\
I tried to abstain from being in a smoking environment & 141 & 55.3 \\
I increased hours of sleep per night & 126 & 49.4 \\
I controlled my weight & 106 & 41.6 \\
I took part in regular exercise & 89 & 34.9 \\
(walking, swimming, etc.) & & \\
I found new leisure activities & 37 & 14.5 \\
I have not made any changes & 25 & 9.8 \\
I gave up my job & 20 & 7.8 \\
I attended an antenatal class & 15 & 5.9 \\
\hline
\end{tabular}

*Marked more than one option

\section{Discussion}

Many reports have indicated that promoting a healthy lifestyles has an important role especially among pregnant women as well as the general public. ${ }^{19,22}$ In the current study the HPLP score of pregnant women was between the upper and intermediate levels $(130.7 \pm 20.0)$. Due to the lack of studies conducted among pregnant women using HPLP II in Turkey we had to compare our findings with the following studies, which did not have a sample group similar to ours. In their study of high risk pregnancies among Turkish women, Saydam, et al. (2007) found that the mean HPLP II score was 121.3 $\pm 21.0 .{ }^{4}$ Altiparmak and Kutlu (2009) reported that it was $112.7 \pm 20.8$ among women aged 15-49 chosen by a random sampling method from the Turkish city of Manisa. ${ }^{11}$ Sayan (1998) found that it was $122.5 \pm 14.5$ among employed women.12 We found that our HPLP II score was higher than that of the previous studies. This difference can be due to the fact that our sample group had a higher level of education and the participants were volunteer pregnant women. Those who volunteered became more motivated about the pregnancy and exhibited a healthier lifestyle. In the only study in which HPLP II scores were investigated among pregnant women even if they were high risk pregnancies 4 the HPLP II scores were lower than ours. This difference may be due to the fact that the women in this earlier study were at high risk, whereas the women in our study were not at high risk. There are two studies from outside Turkey with similar findings. One was conducted by Gharaibeh, et.al. (2005) among 400 pregnant women from Jordan. ${ }^{23}$ The second one was conducted by Lin, et.al. (2009) with 172 pregnant Taiwanese women. ${ }^{1}$ The HPLP-II scores were at the same intermediate levels as ours.

In the current study the lowest score was for physical activity $(8.3 \pm 3.2)$. Saydam, et al. ${ }^{4}$ and Altıparmak and Kutlu ${ }^{11}$ also found that the lowest subscale score was for physical activity (7.8 \pm 3.3$)$. These findings suggest that a lack of physical activity is a problem among women not only during pregnancy but also at any period of their lives. This matches observations of similar studies conducted in Persia which were of 326 pregnant women and also of a study of 172 pregnant Taiwanese women. ${ }^{24}$ Their findings showed that habits of low physical 
activity were common among other communities, comparable to the situation in Turkey. It is well-known that pregnant women who suffered from nausea, vomiting, weakness, fatigue in the first trimester, and limitation of movement in third trimester might abstain from physical activity. In this study, the sample group was in their second trimester (the mean gestational week was $25.2 \pm 10.9$ ). The second trimester is free of the pregnancy related complaints mentioned above. Even if they were free those kind of complaints, we can say their physical activity level was not as high as desired.

In our study, we found that the highest score was for psychological wellbeing which is similar to those of Saydam, et al (2007) and Altiparmak and Kutlu (2009) which were also conducted in Turkey, as well as to the study from Jordon by Gharaibeh et al. (2005).4, 11, 23

In our study, the HPLP-II score was associated with a higher level of education, higher economic status, being employed and living in a nuclear family. Likewise, Lin et. al. (2009) reported similar results regarding the association between the HPLP-II score and the level of education and economic status. ${ }^{1}$ Also Saydam, et al. (2007) found that the total HPLP-II score was higher among working pregnant women. ${ }^{4}$

According to our results the level of education was prominent among the variables mentioned above. Because the level of education was only one variable, this had an impact on all of the subscales of the HPLP II. In the literature it has been reported that the level of education has an important role on the individual's selfefficiency. ${ }^{4}$ Predictably an increased level of education had a positive effect on the women's lifestyles. A similar result was reported by Croizer, et al. whose study was conducted with 1490 British pregnant women (2009). ${ }^{25}$ Some other studies also found that health promoting lifestyles are associated with level of education, in agreement with our findings. ${ }^{24,26}$

In our study, an earlier consideration to terminate the pregnancy was found to be $\mathrm{n}$ inversely associated factor with a e healthy lifestyles during the pregnancy. We thought that unwanted pregnancies may be the cause of unhealthy lifestyles in pregnant women. The total health responsibility and also stress management scores were lower in the group who had considered terminating the pregnancy than to not to consider terminating. Yadollahi, et al. (2007) reported similar findings to ours. ${ }^{24}$

The pregnant women reported having experienced positive changes regarding dietary habits and daily activities in this study. They also said they had regular prenatal visits during pregnancy $(74.9 \%)$ and looked for information about pregnancy and birth (63.1\%). This may indicate a need for women reaching consultancy services during pregnancy.

Giving up smoking during pregnancy was recorded as the most important factor among the variables. We thought that giving up smoking was an important factor because of side effects of smoking on pregnancy. Similar results were found by Croizer, et al. (2009) conducted in England $^{25}$, Zhao, et al. (2011) from the USA ${ }^{27}$, and Bonati and Fellin (1991) conducted in Italy. ${ }^{28}$ They reported that there was a decrease in the rate of smoking and alcohol consumption during pregnancy. The changes in lifestyle during pregnancy are shown in Table 3. According to the findings in the Table 2 such as abstaining from hard activities (63.9\%), taking medicine regularly when prescribed by a doctor $(63.1 \%)$ and seeking information regarding pregnancy and delivery (63.1\%), are things the importance of which as health promoting lifestyles pregnant women are aware of during pregnancy.

Even if the rate of smoking during pregnancy was low in this study, $3.8 \%$ of the women still continued to smoke during pregnancy. This rate was similar to that in a study conducted in Erzurum-Turkey by Alp et al. (1995). ${ }^{29}$ The rates of smoking during pregnancy in Erzurum, Bursa, Istanbul, Samsun and Trabzon were 3\%, 16\%, 32\%, $37 \%, 16.4 \%$ respectively. ${ }^{29-33}$ In the present study, the rate of smoking during pregnancy 
was $3.9 \%$. This rate can be assumed to be high because of the known adverse effects of smoking on the fetus and on pregnancy. Health caregivers should provide information about this matter during antenatal period and should be supportive on smoking cessation. The participants were not recorded as alcohol consumers both before and during pregnancy.

\section{References}

1. Lin YH, Tsai EM, Chan TF, Chou FH, Lin YL. Health Promoting Lifestyles and Related Factors in Pregnant Women. Chang Gung Med J 2009; 32(6): 650-661.

2. Karadeniz G, Ucum EY, Dereli O, Karaagac 0. Üniversite Öğrencilerinin Sağlıklı Yaşam Biçimi Davranışları (The Health Life Style Behaviors of University Students). TAF Prev Med Bull 2008; 7(6): 497-502.

3. Özkan S, Yilmaz E. Hastanede Çalışan Hemşirelerin Sağlıklı Yaşam Biçimi Davranışları (The Health-promoting Lifestyles of Nurses Working at Hospital). Journal of Firat Health Services 2008; 3(7): 89-105.

4. Saydam B, Bozkurt OD, Hadımlı AP, Can HO, Soğukpınar N. Riskli Gebelerde ÖzBakım Gücünün Sağlıklı Yaşam Biçimi Davranışlarına Etkisinin İncelenmesi (Evaluation of the Effects of Self-care Capacity on Healthy Life Style Behaviors in Risky Pregnant). Perinatal Journal 2007; 15(3):131-139.

5. Taşkın L. Doğum ve Kadın Sağlığı Hemşireliği (Maternity Nursing). Ankara: Sistem Ofset Publisher, 2005.

6. Güngör I, Beji NK. İnfertil Çiftlerde Sağlıklı Yașam Biçimi Davranıșları Geliștirme ve Hemșirenin Rolü (Development of Healthy Lifestyle Behaviors in Infertile Couples and Nursing Roles). In: Beji NK, editor. İnfertilite Hemşireliği (Infertilty Nursing). Istanbul: Acar Publisher, 2009. p. 163-176.

7. Anderson K, Nisenblat V, Norman R. Lifestyle Factors in People Seeking Infertility Treatment - A Review. Aust N Z J Obstet Gynaecol 2010; 50 (1): 8-20.
8. Tiedje L, Kingry MJ, Stommel M. Patient Attitudes Concerning Health Behaviors During Pregnancy: Initial Development of a Questionnaire. Health Educ Q 1992; 19(4): 481-493.

9. Mcfarlane J, Parker B, Soeken K. Abuse During Pregnancy: Associations with Maternal Health and Infant Birth Weight. Nurs Res 1996; 45(1): 37-42.

10. Stacy RD, Greer DL, Haas S, Hellbusch JH. Beliefs of Pregnant Women About Smoking and Maternal and Infant Health. Health Values: The Journal of Health Behavior, Education \& Promotion; 1994; 18(5):13-18.

11. Altıparmak S, Kutlu A. 15-49 Yaş Grubu Kadınlarda Sağlığı Geliştirme Davranışları ve Etkileyen Faktörler (The Healthy Lifestyle Behaviors of 15-49 Age Group Women and Affecting Factors). TAF Prev Med Bull 2009; 8(5): 421-426.

12. Sayan A. Çalışan Kadınların Sağlığı Geliştirici Tutum ve Davranışları ile ÖzBakım Gücü Arasındaki İlişkinin Değerlendirilmesi (The Evaluation of Relation Working Women's Health Promoting Attitudes and Behaviors Between Their Self-care Agency). Journal of Anatolia Nursing and Sciences 2001; 4(2): 11-19.

13. Doğu S, Ergin A. Gebe kadınların sigara kullanımı etkileyen faktörler ve gebelikteki zaralarına ilişkin bilgileri. Maltepe Üniversitesi Hemşirelik Bilim ve Sanatı Dergisi 2008; 1(1): 26-39.

14. Altıparmak S, Altıparmak O, Avcı H. Manisa'da Gebelikte Sigara Kullanımı; Yarı Kentsel Alan Örneği. Tur Toraks Der 2009;10:20-25.

15. Gümüş İ, Karakurt F, Kargılı A, Turhan N, Uyar M. Association between prepregnancy body mass index, gestational weight gain, and perinatal outcomes. Turk J Med Sci 2010; 40 (3): 365-370.

16. Noğay N. Gebe kadınların beslenme durumlarının değerlendirilmesi. Electronic Journal of Vocational Colleges 2011; Aralık: 51-57.

17. The Report of Population by 2011. In: Turkey Statistic Institute [online]. Erișim Yeri:www.tuik.gov.tr/PreHaberBultenleri.d 
o?id=10736. Erişim Tarihi: September 01, 2012.

18. Walker SN, Sechrist KR, Pender NJ. The Health Promoting Lifestyle Profile Development and Psychometric Characteristics. Nursing Research 1987; 36(2): 76-80.

19. Esin MN. Sağlıklı Yaşam Biçimi Davranışları Ölçeğinin Türkçe'ye Uyarlanması (The Reliability and Validity Study of Healthy Life Style Behavior Scale in Turkish). Nursing Bulten 1999; 12:45.

20. Akça S. Üniversite Öğretim Elemanlarının Sağlığı Geliştirme Davranışları ve Bunu Etkileyen Etmenlerin Değerlendirilmesi (Health Promoting Behaviors of the Lecturers and Factors Determining These Behavior). Master of Science Thesis, Ege University Health Sciences Institution, Izmir, 1998.

21. Bahar Z, Beşer A, Gordes N, Ersin F, Kıssal A. Sağlıklı Yaşam Biçimi Davranışları Ölçeği II'nin Geçerlik ve Güvenirlik Çalıșması (Healthy Life Style Behavior Scale II: A Reliability and Validity Study). Journal of Cumhuriyet University Nursing School 2008; 12(1): 1-13.

22. Bonati M, Fellin G, ICGDUP (Italian Collaborative Group on Drug Use in Pregnancy). Changes in Smoking and Drinking Behavior Before and During Pregnancy in Italian Mothers: Implications for Public Health Intervention. Int. J. Epidemiol 1991; 20(4): 927-932.

23. Gharaibeh $\mathrm{M}, \mathrm{Al}-\mathrm{Ma}$ 'aitah $\mathrm{R}, \mathrm{Al}$ Jada $\mathrm{N}$. Lifestyle Practices of Jordian Pregnant Women. Int Nurs Rev 2005; 52(2): 92-100.

24. Yadollahi P, Davazdahemami S, Bromandfar K, Fathizadeh N. The Relationship Between Life Style and Individual Reproductive Characteristics of Pregnant Women. Iran J Nurs Midwifery Res 2007; 123(2): 75-79.

25. Croizer SR, et al. Do Women Change Their Health Behaviors in Pregnancy? Findings from the Southam. Pediatrics and Perinatal Epidemiology 2009; 23(5): 446453.
26. Clissold TL, Hopkins WG, Seddon RJ. Lifestyle Behaviours During Pregnancy. NZ Med J 1991; 104(908): 111-2.

27. Zhao G, Ford ES, Tsai J, et al. Trends in Health-related Behavioral Risk Factors Among Pregnant Women in the United States: 2001-2009. J Womens Health (Larchmt) 2012; 21(3): 255-263.

28. Bonati M, Fellin G, ICGDUP (Italian Collaborative Group on Drug Use in Pregnancy). Changes in Smoking and Drinking Behavior Before and During Pregnancy in Italian Mothers: Implications for Public Health Intervention. Int. J. Epidemiol 1991; 20(4): 927-932.

29. Alp H, Selimoğlu MA, Yaman S, Energin M, Altınkaynak S, Orbak Z. Gebelikte Sigara Kullanımının Fetüse Etkileri (The Effects of Smoking to the Fetus During Pregnancy). Journal of Istanbul Pediatric Clinic 1995; 30(1): 80-83.

30. Uncu YA. Gebelikte asemptomatik bakteriüri sıklığı ve gebelik komplikasyonları ile ilişkisi (The prevalence of asymptomatic bacteriuria in pregnancy and association with pregnancy complications). Uludağ Üniversitesi Tıp Fakültesi Aile Hekimliği AD Uzmanlık Tezi, 1999.

31. Özsoy S. Gebelikte sigara içme alıșkanlığı ve evde sigara içilmesinin doğum şekli ve bebeğin doğum tartısı üzerine etkisi (The habit of smoking in pregnancy and the effects of smoking in the house on delivery type and birth weight of the baby). Hemşirelik Bülteni 1999; 5:25-26.

32. Üstün C, Malaytalığlu E. Gebelikte sigara kullanımının fetüs ve plasenta üzerine etkileri (Effects of smoking during pregnancy on the fetus and placenta). Ondokuz Mayıs Üniversitesi Tıp Fakültesi Dergisi 1990; 7(1):43-48.

33. Aktaş S. Gebelik boyunca sigara içiminin perinatal dönemde anne ve bebek sağlığı üzerine etkisi (The effect onhealth mother and newborn of smoking during preagnancy in perinatal period). Cumhuriyet Üniversitesi Sağlık Bilimleri Enstitüsü Kadın Hastalıkları ve Doğum Hemşireliği AD, Yüksek Lisans Tezi, 2006. 